https://doi.org/10.32689/2708-7530-2020-1(1)-119-134

Щиріна Катерина Василівна, аспірантка кафедри управління охороною здоров’я Національної медичної академії післядипломної освіти імені П. Л. Шупика, вул. Дорогожицька, 9, Київ, Україна 04112, тел. +380989792999, еmail:shchyrinak@gmail.com , https://orcid.org/0000-0002-4187-4017

Толстанов Олександр Костянтинович, доктор медичних наук, професор, професор кафедри управління охороною здоров’я Національної медичної академії післядипломної освіти імені П. Л. Шупика, вул. Дорогожицька, 9, Київ, Україна 04112, тел. +380503135281, e-mail: tol.alexandr@gmail.com, https//orcid.org/0000-0002-7459-8629

\title{
ОСНОВНІ ТЕОРЕТИКО-МЕТОДОЛОГІЧНІ ПІДХОДИ ДО УПРАВЛІННЯ МЕДИЧНИМ ЗАКЛАДОМ В УМОВАХ КРИЗИ
}

Анотація. У статті систематизовано теоретико-методологічні підходи до управління медичним закладом в умовах кризи: системний підхід, програмноцільовий підхід, клієнто орієнтований, процесний підхід на основі внесення інновацій та вирішення системних проблем, прагматичний підхід на основі доказової медицини, прикладний підхід. Встановлено, що до найбільш ефективних інструментів управління розвитком сьогодні відносять програмноцільові підходи, а саме: стратегічне планування, кластерний та проектний підхід для концентрації ресурсів у процесі реалізації стратегій та програм розвитку діяльності, програмно-цільове формування бюджету та інші. Перспективним еволюційний шляхом розвитку закладів охорони здоров'я $\epsilon$ впровадження інноваційних підходів до управління. Базовими концепціями сучасних управлінських технологій в охороні здоров'я $\epsilon$ системний та процесний підходи, прийняття рішень, заснованих на доказах, впровадження концепції Total Quality Management (TQM) - тотального управління якістю. Системний підхід базується на основі процесного підходу впровадженні інновацій управлінської діяльності, елементами якого є цикл «Плануй - роби перевіряй - впливай» на базі моделі безперервного поліпшення процесів. Процесний підхід передбачає здійснення детального опису всіх процесів, які відбуваються в організації, систематичне визначення їх взаємодій та керування ними для досягнення запланованих результатів. 
В статті встановлено, що найбільш поширеними та дієвими можна визначити системний та процесний, які орієнтуються на надання якісних медичних послуг та передбачають системність управління усіма процесами медичного закладу. До найбільш ефективних інструментів управління розвитком сьогодні відносять програмно-цільові підходи, а саме: стратегічне планування, кластерний та проектний підхід для концентрації ресурсів у процесі реалізації стратегій та програм розвитку діяльності, програмно-цільове формування бюджету та інші. Перспективним еволюційний шляхом розвитку закладів охорони здоров'я $\epsilon$ впровадження інноваційних підходів до управління. Базовими концепціями сучасних управлінських технологій в охороні здоров'я в умовах кризи є системний та процесний підходи, прийняття рішень, заснованих на доказах, впровадження концепції Total Quality Management (TQM) - тотального управління якістю. Системний підхід базується на основі процесного підходу впровадженні інновацій управлінської діяльності, елементами якого є цикл «Плануй - роби - перевіряй - впливай» на базі моделі безперервного поліпшення процесів. Процесний підхід передбачає здійснення детального опису всіх процесів, які відбуваються в організації, систематичне визначення їх взаємодій та керування ними для досягнення запланованих результатів.

Ключові слова: системний підхід, програмно-цільовий підхід, управління медичним закладом, процесний підхід, прагматичний підхід.

Shchyrina Katherine Vasilyevna, graduate student of the Department of Health Management of the PL Shupyk National Medical Academy of Postgraduate Education, Dorohozhytska Street 9, Kyiv, Ukraine, 04112, tel: +380989792999 , email: shchyrinak@gmail.com, https://orcid.org/0000-0002-4187-4017

Tolstanov Alexander Konstantinovich, Doctor of Medical Sciences, Professor, Professor of the Department of Health Management of the PL Shupyk National Medical Academy of Postgraduate Education, Dorohozhytska Street 9, Kyiv, Ukraine, 04112, tel: +380503135281, e-mail: tol.alexandr@gmail.com, https//orcid.org/0000-0002-7459-8629

\section{MAIN THEORETICAL AND METHODOLOGICAL APPROACHES TO THE MANAGEMENT OF A MEDICAL INSTITUTION IN A CRISIS}

Abstract. The article systematizes theoretical and methodological approaches to the management of a medical institution in a crisis: system approach, program- 
targeted approach, client-oriented, process approach based on innovation and solving system problems, pragmatic approach based on evidence-based medicine, applied approach. It is established that nowadays the most effective tools for development management are program-target approaches: strategic planning, cluster and project approach for concentration of resources in the implementation of strategies and programs of development, program-target budgeting and others. The implementation of innovative approaches to management is a promising evolutionary path for the development of health care facilities. The basic concepts of modern management technologies in health care are systemic and process approaches, evidence-based decision-making, implementation of the concept of Total Quality Management (TQM). The system approach is based on the process approach to the implementation of management innovations, the elements of which are the cycle "Plan - do - check influence" based on the model of continuous process improvement. The process approach involves the implementation of a detailed description of all processes occurring in the organization, the systematic definition of their interactions and their management to achieve the expected results.

The most common and effective, you can define system and process, which focus on providing quality medical services and provide for the systematic control of all processes of the medical institution. The most effective tools of development management is now considered a goal-oriented approach, namely: strategic planning, cluster and project-based approach to focus its resources in the process of implementation of strategies and programmes for the development activities, program-oriented budgeting and more. Evolutionary way of development of health care institutions is the introduction of innovative management approaches. The basic concepts of modern managerial technologies in health care in crisis is a systemic and process approaches, decision-making, evidence-based, introduction of the concept of Total Quality Management (TQM) - total quality management. A systematic approach based on the process approach innovation management activities, which includes the cycle of "plan - do - check - work" on a model of continuous improvement processes. The process approach assumes the implementation detailed descriptions of all processes that occur in organizations, a systematic identification of interactions and their management to achieve the planned results.

Keywords: system approach, program-target approach, medical institution management, process approach, pragmatic approach.

Постановка проблеми. За оцінками Всесвітньої організації охорони здоров'я управління медичними закладами в Україні за останні двадцять років можна охарактеризувати як таке, що призводить до кризового стану, про що 
вказують такі показники: низький рівень поточних витрат на охорону здоров'я на душу населення 125 дол. [1] та поточних витрат на охорону здоров'я у відсотках до валового внутрішнього продукту 6,1\% [2], внутрішні приватні витрати на охорону здоров'я 51,5\% [3] (у відсотках від поточних витрат на охорону здоров'я), витрати населення "з власних кишень" становлять 47,8\% [4] від поточних витрат. Неплатоспроможність населення, нестача фінансування та державних гарантій забезпечення якісних медичних послуг, низький рівень матеріально-технічного забезпечення медичних закладів зумовили кризову ситуацію системи охорони здоров'я, яка має прояв у високих показниках захворюваності населення та низькій якості медичних послуг. Зазначене потребує дослідження теоретико-методологічних підходів до управління медичним закладом в умовах кризи.

Аналіз останніх досліджень та публікацій. Проблематику ефективності та доцільності використання підходів до управління медичним закладом в умовах кризи досліджено у працях М. А. Бриль [5], О. Б. Данченко, В. В. Лепський [6], М. О. Кизим, Г. М. Феденко [7], Н. Я. Панчишин, В. Л. Смірнова [8], І. Л. Сазонець, І. Я. Зима [9], С. О. Смирнов та В. Г. Бикова [10], Б. А. Тхориков [11], I. А Чикаренко та С. І. Бородін [12] та інші науковці.

Мета статті полягає у формуванні теоретико-медологічних підходів до управління медичним закладом в умовах кризи.

Виклад основного матеріалу. У науковій літературі обгрунтовано використання різних підходів до управління в закладах охорони здоров’я, зокрема системний, програмно-цільовий, клієнто орієнтований, процесний підхід на основі внесення інновацій та вирішення системних проблем, прагматичний підхід на основі доказової медицини. Варто також виділити компетентісний підхід, який повинні використовувати заклади охорони здоров’я в управлінській діяльності.

У середині минулого століття в наукових роботах 3 управління організаціями спостерігаються якісні зрушення, що було пов'язано 3 використанням методології системного підходу до управління підприємствами.

Системний підхід - це напрям методології спеціального наукового пізнання та соціальної практики, в основу якого покладено дослідження об’єктів як систем [6]. Система - сукупність елементів, які перебувають у зв’язку та відношеннях між собою, що утворюють визначену цілісність, єдність.

У галузі охорони здоров'я організація процесу надання медичної послуги будується на системі виробничих відносин, ієрархічних зв'язках та на системі правил, прав, відповідальності, обов'язків тощо. 
До найбільш ефективних інструментів управління розвитком сьогодні вже апріорі відносять програмно-цільові підходи, а саме: стратегічне планування, кластерний та проектний підхід для концентрації ресурсів у процесі реалізації стратегій та програм розвитку діяльності, програмно-цільове формування бюджету та інші. Ці інструменти, в першу чергу орієнтовані на інноваційний розвиток, на досягнення кінцевих результатів діяльності, які виражаються через задоволення потреб та інтересів закладів охорони здоров'я та отримання ними певних суспільних вигід [12].

Суть програмно-цільового підходу до забезпечення розвитку закладів охорони здоров'я полягає у виявленні проблем, що вимагають дослідження $\mathrm{i}$ ефективного вирішення, розробці стратегічних планів або відправних програм усунення перешкод на шляху досягнення поставлених цілей, формуванні відповідних напрямів управління [5].

Програмно-цільовий підхід $є$ однією 3 основних форм комплексного, системного підходу до процесів управління об'єктами, процесами, відносинами різної природи та змісту, способом вирішення великих і складних завдань за допомогою вироблення та здійснення системи програмних заходів, орієнтованих на цілі, досягнення яких забезпечує розв'язання проблем, що виникли. Його застосування полягає у визначенні конкретних ресурсів для вирішення комплексних проблем, гармонізації усіх видів діяльності, активностей та заходів, які здійснюються окремими інституціями й різними рівнями управління, відстеженні результативності прийнятих рішень та виконаних завдань. Основний акцент використання програмно-цільового підходу в державному управлінні ставиться на необхідності досягнення максимального соціально вагомого ефекту в результаті використання коштів, сплачених платниками податків. Тобто кінцевим результатом випливу програмно-цільового підходу є забезпечення рівного доступу кожному індивіду до усіх необхідних послуг належної якості. Такий підхід має бути постійним і безперервним.

Поняття «програмно-цільове управління» трактується в широкому сенсі і як метод програмного втілення управлінських рішень, i як реалізація комплексного підходу при вирішенні соціально-економічних проблем. Програму розглядають як інструмент змін, вибраний 3 декількох альтернативних варіантів як найбільш ефективний шлях досягнення намічених результатів. Поняття «цільова» передбачає спрямованість програм на досягнення заздалегідь встановленої, чітко визначеної мети [7].

Сутність програмно-цільового підходу полягає у використанні схеми: «проблема - мета - рішення - програма - бюджет - контроль», тобто наявні 
управлінські проблеми визначають цілі їх вирішення, досягнення яких потребує певного плану заходів, складання і оптимізації бюджету та контролю його виконання. Його реалізація вимагає наявності відповідної методологічної бази, кваліфікованих фахівців i програмно обчислювальних комплексів, що ускладнює його застосування в умовах приватних закладів охорони здоров'я, проте за певних умов [10].

На практиці програмно-цільовий підхід реалізується через регіональні цільові програми (РЦП) та забезпечує прямий взаємозв'язок між розподілом бюджетних ресурсів та фактичними чи запланованими результатами їх використання відповідно до встановлених пріоритетів державної політики. Перевагами застосування цього методу слід відзначити створення фінансово ресурсного забезпечення для досягнення поставлених цілей та гарантію цільової спрямованості їх використання.

Перспективним еволюційний шляхом розвитку закладів охорони здоров'я $\epsilon$ впровадження інноваційних підходів до управління. Розвиток інновацій рушійна сила організаційних змін, оскільки впливає на процеси медичного обслуговування, як наслідок оптимізує структуру медичних послуг. Від впровадження інновацій в медичному закладі залежить результативність зусиль щодо реформування галузі у цілому.

Інновації можуть проявлятися в нових процесах, методах роботи, технологіях, нових підходах до організації роботи. Ключову організаційнометодичну роль у визначенні основних напрямків вдосконалення, розробці та реалізації інноваційних перетворень відіграють управлінські технології. У працях багатьох вчених простежується і така точка зору на систему охорону здоров'я і призначення закладів медичних послуг, згідно з якою медична діяльність набуває інноваційної спрямованості. Прикладом такої точки зору може слугувати Сербія, де було успішно здійснено ряд проектів, спрямованих на створення електронної системи охорони здоров'я. Згідно 3 програмою підтримки, розвитку та стабілізації базових лікувально-профілактичних i фармацевтичних послуг було розроблено електронні медичні карти для закладів охорони здоров'я Сербії.

Базовими концепціями сучасних управлінських технологій в охороні здоров'я є системний та процесний підходи, прийняття рішень, заснованих на доказах, впровадження концепції Total Quality Management (TQM) - тотального управління якістю.

Залежно від концептуальної частини розрізняють такі інноваційні підходи організаційного вдосконалення та менеджменту якості: модель TQM, організаційна самооцінка, безперервне поліпшення якості, модель 
Європейського фонду управління якістю - ЄФУЯ, модель ЕFQМ, цикл Демінга-Шухарта плануй-виконуй-перевіряй-корегуй, 3 яких останніми роками виокремився підхід 6 сигм, аудит зі зворотнім зв'язком тощо.

Управлінські технології розвитку здатності організації ставити i досягати цілі щодо задоволення усіх потреб зацікавлених сторін сконцентровано у вигляді фундаментальної концепції менеджменту якості або моделі ідеальних організацій.

Варто відзначити, що в Україні у зв'язку з реалізацією Національної стратегії реформування системи охорони здоров'я в Україні на період 2015-2020 років [13] впроваджуються нові стратегічні підходи до підвищення якості та доступності медичної допомоги та зменшення фінансових ризиків для населення, формується нова модель медичної допомоги. Сьогодні відбувається перехід від моделі М. О. Семашка, де система є державною власністю та орієнтована на лікарні, з дуже фрагментованим управлінням та послугами, зосередженими на лікуванні гострих випадків при мінімальній профілактиці, до нової моделі за принципом «гроші йдуть за пацієнтом». Нова модель охорони здоров'я передбачає спрямування усіх напрямків медицини до нового рівня якісного обслуговування та сучасних вимог європейського рівня. Одним $з$ напрямків змін $є$ автономізація постачальників медичної допомоги, перетворення лікарень у комунальні неприбуткові підприємства.

Для контролю за діяльністю медичного закладу формуються спостережні та наглядові ради, до яких входитимуть представники медичного закладу, органи місцевого самоврядування, місцеві депутати та представники громади.

Інструменти, які сьогодні мають головні лікарі та керівники медичних закладів приватної форми власності, так само матимуть і керівники державних та комунальних лікарень.

В результаті проведення реформ зростатиме якість медичних послуг державних та комунальних закладів охорони здоров'я, ефективність організації їх роботи. Тому зростатиме рівень конкуренції в галузі медицини в цілому. Приватні клініки повинні впроваджувати інновації в організації роботи задля забезпечення ефективності діяльності та зростання якості медичних послуг, доступності та популяризації приватної медицини в Україні.

На основі прагматичного підходу та доказової медицини в Україні запроваджуватиметься державно-приватне партнерство, особливо у сфері лабораторної діагностики.

Для закладів охорони здоров’я відкриваються нові механізми залучення фінансових ресурсів, серед яких: співпраця 3 благодійними фондами та організаціями, розвиток співпраці зі страховими компаніями, міжнародними 
організаціями, що працюють в сфері надання медичних послуг та модернізації систем управління медициною, створення підрозділів лікарні, які працюють на комерційних принципах, розвиток діяльності лікарняних кас [9].

Робота у складних умовах реформування вимагає наявності у керівників закладів охорони здоров'я певного арсеналу особистих та професійних якостей, відсутність яких веде до формування численних управлінських обмежень та $є$ перешкодою на шляху модернізації галузі.

Інші дослідження також підтверджують неефективність управління закладами охорони здоров’я через наслідки управлінської діяльності пострадянської адміністративно-командної моделі за принципом згори-вниз. Модифікації управління закладами охорони здоров’я останніх років не внесли кардинальних змін у застарілі підходи до менеджменту. Переважна частина управлінських методів, що використовуються у закладах охорони здоров'я, запозичені або з радянської моделі, або 3 інших галузей, неефективна i не відповідає основним завданням, що стоять перед системою О3 [9].

Натепер у повсякденній професійній діяльності керівників закладів охорони здоров'я переважає господарча та фінансова діяльність, а також забезпечення закладу необхідними для діяльності ресурсами (сукупна частка даних видів діяльності найбільша - 39,97\%). Це кореспондується 3 дослідженнями інших українських фахівців, згідно 3 якими у діяльності головних лікарів переважає господарча робота, а не творча управлінська діяльність [8]. Отже, в управлінській діяльності закладів охорони здоров’я на сьогодні відсутній творчий підхід до організації діяльності, який передбачає впровадження інноваційних методів роботи закладу, інновацій в організації управлінської діяльності та управлінських технологій.

У операційному керівництві MO3 «Як організувати систему надання первинної медичної допомоги на місцевому рівні» [14] визначено два найбільш ефективні підходи системний та прикладний.

Системний на основі процесного підходу впровадженні інновацій управлінської діяльності, елементами якого є цикл «Плануй - роби - перевіряй - впливай» на базі моделі безперервного поліпшення процесів. Процесний підхід передбачає здійснення детального опису всіх процесів, які відбуваються в організації, систематичне визначення їх взаємодій та керування ними для досягнення запланованих результатів. Прикладами процесів в організації, яка надає ПМД, можуть бути «Запис на консультацію до лікаря», «Відвідування пацієнта вдома», «Спілкування 3 пацієнтами телефоном», «Направлення до вузькопрофільних фахівців» тощо. 
На «вході» в систему існують вимоги (очікування) отримувачів послуг (пацієнтів), на «виході» - послуги, які задовольняють ці потреби. Ступінь задоволеності пацієнтів визначається шляхом вимірювання. Відповідальність керівництва передбачає, що керівники постійно підтримують фокус уваги організації на потребах пацієнтів та вимогах законодавства, встановлюють чіткі цілі забезпечення якості та сприяють їх усвідомленню всіма співробітниками, забезпечують наявність необхідних ресурсів. I через управління ресурсами здійснюється удосконалення якості послуг для кращого задоволення потреб споживачів (пацієнтів).

Отже, розглянемо наступну модель: вихід - надання медичної послуги, вхід - ресурси та інформація. Застосування системного підходу починається 3 проведення маркетингових досліджень і формування параметрів виходу (надання медичної послуги): яку послугу надавати, з якими показниками якості, які витрати на ії надання, у які терміни, хто буде споживачем послуги, за якою ціною тощо. На всі ці запитання відповідь потрібно надати одночасно.

Медична послуга має бути конкурентоспроможною. Потім необхідно визначити параметри входу: які потрібні ресурси і яка інформація. Потреба в ресурсах та інформації прогнозується після вивчення організаційно-технічного рівня системи (рівень кваліфікації персоналу, якість обладнання, технології, організація праці, управління) та параметрів зовнішнього середовища (політичної, економічної, соціально-демографічної, культурної ситуації та інфраструктури конкретного об'єкта).

Зворотний зв'язок є комунікативним каналом від отримувачів послуги до iï надавачів. У разі зміни вимог користувачів до медичних послуг, параметрів ринку, появи нових технологій система має відреагувати на ці зміни і внести відповідні зміни в параметри функціонування. Реакція системи відображається в плануванні, зміні функцій усередині організації. Організація є основною складовою і забезпечує взаємодію між підсистемами та всією системою. Організація об'єднує ресурси (людей, матеріальні засоби, фінанси) і визначає правила (права та відповідальність). Особливості системного підходу в керівництві медичними закладами.

Особливістю системи надання медичних послуг $є$ відсутність виробництва в технічному розумінні цього слова. Процес надання медичної послуги є комбінацією з праці медичного персоналу і медичного обладнання, необхідного для надання цієї послуги. Під обладнанням ми розуміємо будь-які матеріальні речі, що необхідні для надання медичної послуги.

Прикладний підхід передбачає використання окремих елементів СУЯ дозволяє отримати швидкі результати в підвищенні якості послуг ПМД, які відчують 
споживачі (пацієнти). Такі результати також можуть мотивувати команду ПМД до подальшого впровадження більш системного підходу зі створенням повноцінної СУЯ. Головна передумова таких точкових змін - це визнання всіма членами команди ПМД декількох важливих принципів:

1. Пацієнт-орієнтованість: заклад ПМД працює насамперед для задоволення потреб пацієнтів.

2. Подальше успішне існування закладу ПМД залежить від того, наскільки послуги ПМД відповідають потребам пацієнтів.

3. Для визначення задоволеності пацієнтів їі необхідно вимірювати.

4. На підставі вимірювання необхідно вносити зміни в реальну практику надання послуг.

Як засвідчує досвід управління командами, група не зможе досягти успіху, доки всі ії члени не поділятимуть спільних цінностей та принципів. Заміна членів команди, які не поділяють спільних цінностей, на однодумців найбільш ефективний шлях до досягнення поставлених цілей. Особливо це стосується медичних закладів, де певні цінності (позитивне ставлення до людей, співпереживання, готовність прийти на допомогу ближньому та ін.) закладаються з вихованням і які важко набути в дорослому віці.

Нині в зарубіжних системах охорони здоров'я з'явилася нова парадигма ціннісно-орієнтованої системи охорони здоров'я, яка фокусується на якості наданих медичних послуг за певного рівня витрат, на засадах якої були реалізовані проекти щодо широкомасштабного скорочення витрат, забезпечення сталого розвитку і підвищення ефективності у сфері охорони здоров'я, основною метою яких було збереження колишнього обсягу і якості надання медичних послуг без залучення додаткових фінансових ресурсів. Відповідно дослідженням, часто зростання витрат на охорони здоров'я не пов'язано з результатами лікування, тому існує необхідність прозорості даних щодо результатів лікування. Тому управління має базуватися на підході, в основі якого орієнтація на результат лікування, що можна оцінити на основі показників ефективності лікування. Прикладом застосування цього підходу може служити Швеція, де відзначається чіткий взаємозв'язок між витратами на душу населення та індексом якості [15]. Такий підхід особливо актуальний в Україні, зважаючи на незадовільні показники захворюваності населення та смертності від різних хвороб.

Зарубіжний досвід управління підприємствами охорони здоров'я свідчить про ряд тенденцій i ефективних зарубіжних практик, що $\epsilon$ найбільш актуальними для забезпечення фінансової стійкості та ефективності функціонування медичних закладів в період фінансово-економічної кризи. У 
наукових публікаціях з питань закордонних систем охорони здоров'я велика увага приділяється державній політиці, що стосується організації та фінансування надання медичної допомоги населенню, а також побудови актуальних моделей оптимізації витрат державних і приватних бізнес-структур на медичне обслуговування громадян. На корпоративному і державному рівнях наголошується на необхідності формування регістра для отримання достовірних даних про захворювання, виявлення закономірностей їх виникнення і розвитку, розроблення управлінських рішень щодо профілактики та реабілітації [15].

За даними Світового банку поточні витрати на охорону здоров'я як відношення до ВВП постійно зростають (рис. 1).

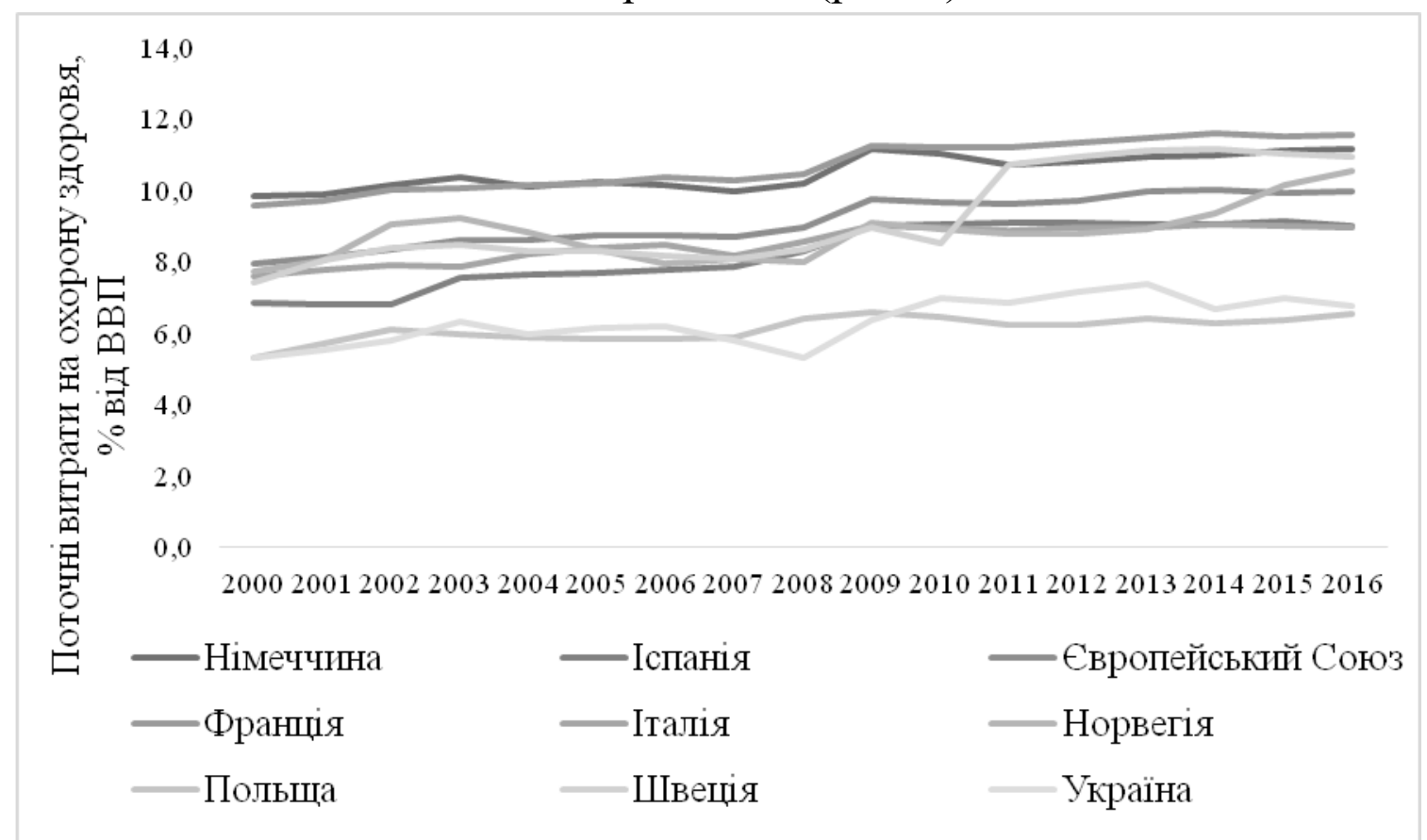

Рис. 1. Динаміка поточних витрат на охорону здоров’я як \% до ВВП Джерело: [16].

Тому в зарубіжній практиці управління постає проблематика розробки такого підходу, який би забезпечив ефективність лікування та надання медичної допомоги разом зі стримуванням витрат державного та приватного секторів. Особливо ситуація загострюється у зв'язку з економічним спадом, коли державні витрати потребують оптимізації та скорочення, відповідно у кризовому стані недофінансування знаходиться і галузь охорони здоров’я.

Тому доцільно використовувати методи довгострокового планування циклічного розвитку медичних закладів, що передбачає планування людських ресурсів, техніки та обладнання, моніторингових та аналітичних систем. 
Сьогодні в розвинених країнах управління медичним закладом базується на поєднанні процесного, системного, соціально-орієнтований та орієнтований на результат підходах в межах підходів, методів та інструментів стратегічного менеджменту. Відтак, завдяки зміні процесів, що стосуються технології лікування, роботи невідкладної допомоги, кадрового забезпечення та матеріально-технічної бази організацій забезпечено ефективність лікування.

Досвід Нідерландів також корисний 3 позицій використання довгострокових стратегій планування ресурсів, процесів, які забезпечуються фахівцями медичних установ. При неефективному використанні ресурсів працівниками можливий перерозподіл ресурсів між тими працівниками, які забезпечуються ефективність використання коштів [10, с. 33].

В американській моделі охорони здоров'я надання медичних послуг відбувається бізнесом в межах соціально відповідальної стратегії розвитку, як складової системи забезпечення мотивації працівників. Відтак, бізнес відповідає за збереження та підтримку здоров'я працівників [15].

Соціально відповідальна стратегія покращення управління медичними закладами використовується у Німеччині. В країні було здійснено впровадження новітніх технологій на основі використання інформаційноаналітичних медичних систем здійснювалося в рамках методології корпорацій «Microsoft» та «Intel» компанією «Asklepios». Німеччина ініціювала та реалізувала таким чином програму реформування національної та міжнародної системи охорони здоров'я «Asklepios» - лікарня майбутнього». Програма забезпечувала медичний персонал сучасними технологіями, які забезпечують оптимізацію та інтеграцію технологій для раціоналізації процесів, прискорення доступу до даних пацієнта. Стандартизовані технології $\epsilon$ провідним інструментом в забезпеченні ефективного управління сучасними підприємствами охорони здоров’я. В ході проекту приватні медичні організації розробили серію ефективних рішень, орієнтованих на «клініку майбутнього», невід'ємними компонентами яких повинні бути масштабованість і гнучка адаптація до будь-якого медичного закладу незалежно від його розміру i спеціалізації. Позитивний вплив цього проекту на основну медичну діяльність полягав в таких моментах [15]:

- можливість швидкого і якісного отримання інформації, необхідної для здійснення лікувально-діагностичного процесу та оформлення медичної документації;

- збільшення рівня комунікації всередині організації;

- зменшення додаткових витрат; 
- зниження рівня адміністративного навантаження і числа помилок через зменшення кількості інформаційних потоків і синхронізації використовуваних технологій;

- зменшення тимчасових витрат в рамках використання інновацій.

Аналіз досвіду європейських країн також продемонстрував успішність використання технологій розвитку закладів охорони здоров'я на основі довгострокового планування, які передбачають оптимізацію бізнес-процесів. Оптимізація передбачає якісну зміну діяльності за рахунок мінімізації та раціонального використання ресурсів, що поширюється на усі підрозділи медичного закладу. 3 використанням зазначеної технології вдалося мінімізувати витрати часу та ресурси на розроблення інновацій, що стосуються медичних приладів та послуг нового покоління, і тим самим підвищити якість медичних послуг.

Висновки. Отже, у зв’язку з реформуванням системи охорони здоров’я та автономізацією закладів охорони здоров'я, в Україні змінюються підходи до організації управлінської діяльності. Найбільш поширеними та дієвими можна визначити системний та процесний, які орієнтуються на надання якісних медичних послуг та передбачають системність управління усіма процесами медичного закладу. До найбільш ефективних інструментів управління розвитком сьогодні відносять програмно-цільові підходи, а саме: стратегічне планування, кластерний та проектний підхід для концентрації ресурсів у процесі реалізації стратегій та програм розвитку діяльності, програмно-цільове формування бюджету та інші. Перспективним еволюційний шляхом розвитку закладів охорони здоров'я $€$ впровадження інноваційних підходів до управління. Базовими концепціями сучасних управлінських технологій в охороні здоров’я в умовах кризи є системний та процесний підходи, прийняття рішень, заснованих на доказах, впровадження концепції Total Quality Management (TQM) - тотального управління якістю. Системний підхід базується на основі процесного підходу впровадженні інновацій управлінської діяльності, елементами якого є цикл «Плануй - роби - перевіряй - впливай» на базі моделі безперервного поліпшення процесів. Процесний підхід передбачає здійснення детального опису всіх процесів, які відбуваються в організації, систематичне визначення їх взаємодій та керування ними для досягнення запланованих результатів.

\section{Jimepamypa:}

1. Бриль М. А. Програмно-цільовий підхід до забезпечення розвитку сільських територій: Дисертація на здобуття наукового ступеня кандидата наук 3 державного 
управління (доктора філософії) за спеціальністю 25.00.04. Національна академія державного управління при Президентові України, Київ, 2019. 219 с.

2. Данченко О. Б., Лепський В. В. Моделі стратегічного менеджменту медичних проектів проектно-орієнтованого медичного закладу. Вісник Національного технічного університету "ХПІ". Серія: Стратегічне управління, управління портфелями, програмами та проектами, 2018. № 2 (1278). С. 45-52.

3. Кизим М. О. Теорія та практика оцінки пріоритетності та результативності державних цільових програм в Україні / М.О. Кизим, Г.М. Феденко // Бізнес Інформ. 2012. № 12. C. 6-13.

4. Національна стратегія реформування системи охорони здоров'я в Україні на період 2015 - 2020 років. URL: http://moz.gov.ua/uploads/0/691-strategiya.pdf (дата звернення 10.08.2019)

5. Панчишин Н. Я. Оцінка ефективності управління в системі охорони здоровея / Н. Я. Панчишин, В. Л. Смірнова // Вісник соц. гігієни та орг. охорони здоровея України. 2012. № 3 (53). С. 57-59.

6. Сазонець I. Л., Зима І. Я. Вдосконалення системи управління охороною здоров'я в рівненській області на основі впровадження проекту світового банку. Інвестиції: практика та досвід. 2018. № 24. С. 49-53.

7. Смирнов С. О. Бикова В. Г. Механізм економічного управління закладами охорони здоров’я // Управління розвитком. 3(185). 2016. С. 78-83.

8. Тхориков Б. А. Проектное управление в ЛПУ : опыт Белгородской области. Здравоохранение. 2012. № 7. С. 28-32.

9. Чикаренко /I. А, Бородін С.І.Програмно-цільовий інструментарій управління розвитком та співробітництвом об'єднаних територіальних громад. URL: https:/graniprint.dp.ua/index.php/home/article/view/100

10. Як організувати систему надання первинної медичної допомоги на місцевому рівні. Операційне керівництво / Баценко Д., Брагінський П., Бучма М. та ін. Міністерство охорони здоров'я України, Проект USAID «Реформа ВІЛ-послуг у дії», ТОВ «Агентство «Україна» $\quad$ К., $2018 . \quad 368 \quad$ c. $\quad$ https://moz.gov.ua/uploads/0/4992phc_operational_manual_apr_2018_fin_web1.pdf

11. Шевченко В.А. Зарубіжний досвід управління закладами охорони здоров’я. Економічний вісник Запорізької державної інженерної академії, № 6-2(06), 2016, С. 9-13.

12. Current health expenditure (CHE) as percentage of gross domestic product (GDP) (\%). URL: http://apps.who.int/gho/data/node.main.GHEDCHEGDPSHA2011?lang=en (date of access 07.11.19)

13. Current health expenditure (CHE) per capita in PPP. URL: http://apps.who.int/gho/data/node.main.GHEDCHEpcPPPSHA2011?lang=en (date of access 07.11.19)

14. Current health expenditure (CHE) per capita in US\$. URL: http://apps.who.int/gho/data/node.main.GHEDCHEpcUSSHA2011?lang=en (date of access 07.11.19)

15. Domestic private health expenditure (PVT-D) as percentage of current health expenditure (CHE) (\%).URL: http://apps.who.int/gho/data/node.main.GHEDPVTDCHESHA2011?lang=en (date of access 07.11.19)

16. World Bank. Current health expenditure (\% of GDP). URL: https://data.worldbank.org/indicator/SH.XPD.CHEX.GD.ZS (date of access 07.11.19) 


\section{References:}

1. Bryl, M. A. (2019). Prohramno-tsilovyi pidkhid do zabezpechennia rozvytku silskykh terytorii [Program-based approach to rural development]. Candidate's thesis. Kyiv: Natsionalna akademiia derzhavnoho upravlinnia pry Prezydentovi Ukrainy [in Ukrainian].

2. Danchenko, O. B., Lepskyi, V. V. (2018). Modeli stratehichnoho menedzhmentu medychnykh proektiv proektno-oriientovanoho medychnoho zakladu [Models of strategic management of medical projects of project-oriented medical institution]. Visnyk Natsionalnoho tekhnichnoho universytetu "KhPI". Seriia: Stratehichne upravlinnia, upravlinnia portfeliamy, prohramamy ta proektamy - Bulletin of the National Technical University "KhPI". Series: Strategic Management, Portfolio, Program and Project Management, 2(1278), 45-52 [in Ukrainian].

3. Kyzym, M. O., Fedenko, H. M. (2012). Teoriia ta praktyka otsinky priorytetnosti ta rezultatyvnosti derzhavnykh tsilovykh prohram $\mathrm{v}$ Ukraini [Theory and practice of assessing the priority and effectiveness of state target programs in Ukraine]. Biznes Inform-Business Inform, 12, 6-13 [in Ukrainian].

4. Natsionalna stratehiia reformuvannia systemy okhorony zdorovia v Ukraini na period 2015 - 2020 rokiv [National strategy for reforming the health care system in Ukraine for the period 2015-2020]. (n.d.). moz.gov.ua. Retrieved from http://moz.gov.ua/uploads/0/691-strategiya.pdf [in Ukrainian].

5. Panchyshyn, N. Ya., Smirnova, V. L. (2012). Otsinka efektyvnosti upravlinnia v systemi okhorony zdorovya [Estimation of management efficiency in the health care system]. Visnyk sots. hihiieny ta orh. okhorony zdorovya Ukrainy - Bulletin of Social Hygiene and Health Protection Organization of Ukraine, 3(53), 57-59 [in Ukrainian].

6. Sazonets, I. L., Zyma, I. Ya. (2018). Vdoskonalennia systemy upravlinnia okhoronoiu zdorovia $\mathrm{v}$ rivnenskii oblasti na osnovi vprovadzhennia proektu svitovoho banku [Improvement of the health care management system in Rivne region based on the implementation of the World Bank project]. Investytsii: praktyka ta dosvid - Investments: practice and experience, 24, 49-53 [in Ukrainian].

7. Smyrnov, S. O., Bykova, V. H. (2016). Mekhanizm ekonomichnoho upravlinnia zakladamy okhorony zdorovia [The mechanism of economic management of health care institutions]. Upravlinnia rozvytkom - Development Management, 3(185), 78-83 [in Ukrainian].

8. Tkhorikov, B. A. (2012). Proektnoe upravlenie v LPU : opyt Belgorodskoy oblasti [Project management in health care facilities: the experience of the Belgorod region]. Zdravookhranenie - Healthcare, 7, 28-32 [in Russian].

9. Chykarenko, I. A, Borodin, Ye. I. (2019). Prohramno-tsilovyi instrumentarii upravlinnia rozvytkom ta spivrobitnytstvom obiednanykh terytorialnykh hromad [Program-target tools for managing the development and cooperation of united territorial communities]. Detsentralizatsiia vlady v Ukraini: otsiniuvannia rezultativ formuvannia ta rozvytku samodostatnikh hromad Decentralization of power in Ukraine: evaluation of the results of formation and development of self-sufficient communities. (pp. 38-43). Retrieved from https://graniprint.dp.ua/index.php/home/article/view/100 [in Ukrainian].

10. Batsenko, D., Brahinskyi, P., Buchma, M., et. al. (2018). Yak orhanizuvaty systemu nadannia pervynnoi medychnoi dopomohy na mistsevomu rivni. Operatsiine kerivnytstvo [How to organize a system of primary health care at the local level. Operational management]. Ministerstvo okhorony zdorovia Ukrainy, Proekt USAID «Reforma VIL-posluh u dii», TOV «Ahentstvo «Ukraina». Kyiv. Retrieved from https://moz.gov.ua/uploads/0/4992phc_operational_manual_apr_2018_fin_web1.pdf [in Ukrainian].

11. Shevchenko, V. A. (2016). Zarubizhnyi dosvid upravlinnia zakladamy okhorony zdorovia [Foreign experience in health care management]. Ekonomichnyi visnyk Zaporizkoi derzhavnoi inzhenernoi akademii - Economic Bulletin of the Zaporozhye State Engineering Academy, 6-2(06), 9-13 [in Ukrainian]. 
12. Current health expenditure (CHE) as percentage of gross domestic product (GDP) (\%). (n.d.). apps.who.int. Retrieved from http://apps.who.int/gho/data/node.main.GHEDCHEGDPSHA2011?lang=en [in English].

13. Current health expenditure (CHE) per capita in PPP. (n.d.). apps.who.int. Retrieved from http://apps.who.int/gho/data/node.main.GHEDCHEpcPPPSHA2011?lang=en [in English].

14. Current health expenditure (CHE) per capita in US\$. (n.d.). apps.who.int. Retrieved from http://apps.who.int/gho/data/node.main.GHEDCHEpcUSSHA2011?lang=en [in English].

15. Domestic private health expenditure (PVT-D) as percentage of current health expenditure (CHE) (\%). (n.d.). apps.who.int. Retrieved from http://apps.who.int/gho/data/node.main.GHEDPVTDCHESHA2011?lang=en [in English].

16. Current health expenditure (\% of GDP). (n.d.). apps.who.int. Retrieved from https://data.worldbank.org/indicator/SH.XPD.CHEX.GD.ZS [in English]. 